\title{
Some aspects of the sediment transport during the 2005 floods in Switzerland
}

\author{
MARTIN JAEGGI \\ River Engineering and Morphology, Ebmatingen, Switzerland
}

\begin{abstract}
Some aspects of the sediment transport during the 2005 floods in Switzerland. In August 2005 a very severe flood hit large parts of Switzerland. Strong erosion occurred in several steep, apparently stable reaches of mountain streams, what produced heavy sediment loads. Where these were deposited, they caused channel avulsion or channel obstruction with subsequent inundations. Numerical simulation proved to be a useful tool to analyse the processes and to plan mitigation measures. In particular, it could be shown that the flooding of the Schächen river had its origin in a lateral overspilling in the final reach of this tributary and a subsequent blocking of the flow section. The load eroded in the upstream reach, which is normally stable because of the presence of big boulders, was sufficient to feed this process. A detention basin with an open slit dam located upstream did only retain a limited amount of sediment temporarily. During flow recession, most of these deposits were eroded. This was in agreement with the original concept, but was not very useful in this flood situation. On the Lütschine river, a similar massive erosion in a steep reach caused widespread deposition in an area where such phenomena did probably not occur over the last 150 years. For such rare events, it is reasonable to plan a deposition area where limited agricultural land use is allowed. Sediment deposition occurs only in function of slope reduction and channel widening; no special structures are planned.
\end{abstract}

Key words: floods, mountain streams, bed morphology, sediment transport, numerical simulation.

\section{INTRODUCTION}

Very severe flooding hit Switzerland, part of Austria and Bavaria on August 21-23, 2005. In the days preceding the flood a low pressure cell developed over Genova inducing a strong circulation around the Alps. This brought warm and humid air from the Adriatic Sea, around the eastern side of the Alps and then brought a strong northern current to hit their northern slopes, leading to prolonged heavy rainfall. Rainfall totals exceeded $200 \mathrm{~mm}$ in 48 hours and $350 \mathrm{~mm}$ during four days. While on worldwide standards this may not be an extreme rainfall, these intensities and the resulting discharges in the rivers were extremely high, on a local standard. For many rivers, discharges exceeded a one hundred year flood as determined form discharge records previous to the flood. Furthermore, the very high discharges and the significant damages were not so much due to the peak rainfall intensity, but rather the long duration of heavy rainfall. This weather situation is not common in Switzerland, but according to the Swiss meteorological service a very similar event occurred in June 1910. 
Flooding affected an unusually large area. The area where damage was recorded extended from Lake of Geneva in the West to the canton of Grisons in the East, covering the whole northern slope of the Alps as well as a large part of the Swiss plateau. First impressions after the flood were presented by the author at the Gravel Bed Rivers Conference VI (Jaeggi 2008). First results of the investigations performed on the causes and effects of these floods are described by Bezzola and Hegg (2007).

In this paper, some aspects of sediment transport during these events are presented. They concern two case studies for which the results were mainly obtained from numerical simulation.

\section{SCHÄCHEN RIVER}

\section{Confluence and lined channel in the lower part}

Figure 1 shows in the foreground the confluence of the Reuss and its tributary, the Schächen river (Canton of Uri, Central Switzerland). This carried a lot of coarse sediment up to stone and block size. This load was almost completely deposited at the confluence, where the main river Reuss was not able to carry all this material away. The deposition then advanced up the lined channel, filling the channel and causing flooding of the neighbouring areas.

In the lower part of the Schächen, on its alluvial fan, the channel was lined in masonry after a similar event occurred in 1910. During that event, deposition and flooding were concentrated at the top of the alluvial fan, about $1.5 \mathrm{~km}$ upstream of the confluence with the Reuss river. It was then hoped that all the bedload material would be easily moved away by the Reuss. Obviously, as the recent event showed, the transport capacity of the Reuss river was however substantially overestimated.

In 1977 an important flood occurred in the Schächen with a peak flow estimated to be about $110 \mathrm{~m}^{3} / \mathrm{s}$. In 2005 , a peak flow of $150 \mathrm{~m}^{3} / \mathrm{s}$ was recorded. More important was the fact that the discharge exceeded $100 \mathrm{~m}^{3} / \mathrm{s}$ for more than 12 hours. This shows how difficult it still is to define a reasonable design flood, even from long records, when between rare major events the discharge remains small, and when the duration of extreme floods is also important.

In the background of Figure 1 the consequences of the deposition spreading upstream may be seen. The channel was completely filled, and then water and sediment spilt into the neighbouring industrial area. The section below the railway bridge was also filled. A hydraulic jump which occurred about $850 \mathrm{~m}$ upstream of the confluence indicated the position to which the deposition front moved upstream. Deposition was as deep as the channel walls in the lower part and about two thirds of the channel depth near the hydraulic jump.

A drainage canal, parallel to the Reuss river and passing in a tunnel underneath the lined channel of the Schächen river, was blocked by sediment spilling from the river channel. The floodplain upstream of the alluvial fan of the Schächen river is lower compared than the beds of both rivers. That is why the tunnel was built. Because of the blockage another big industrial area was flooded for days (located further on the right looking at Figure 1). 


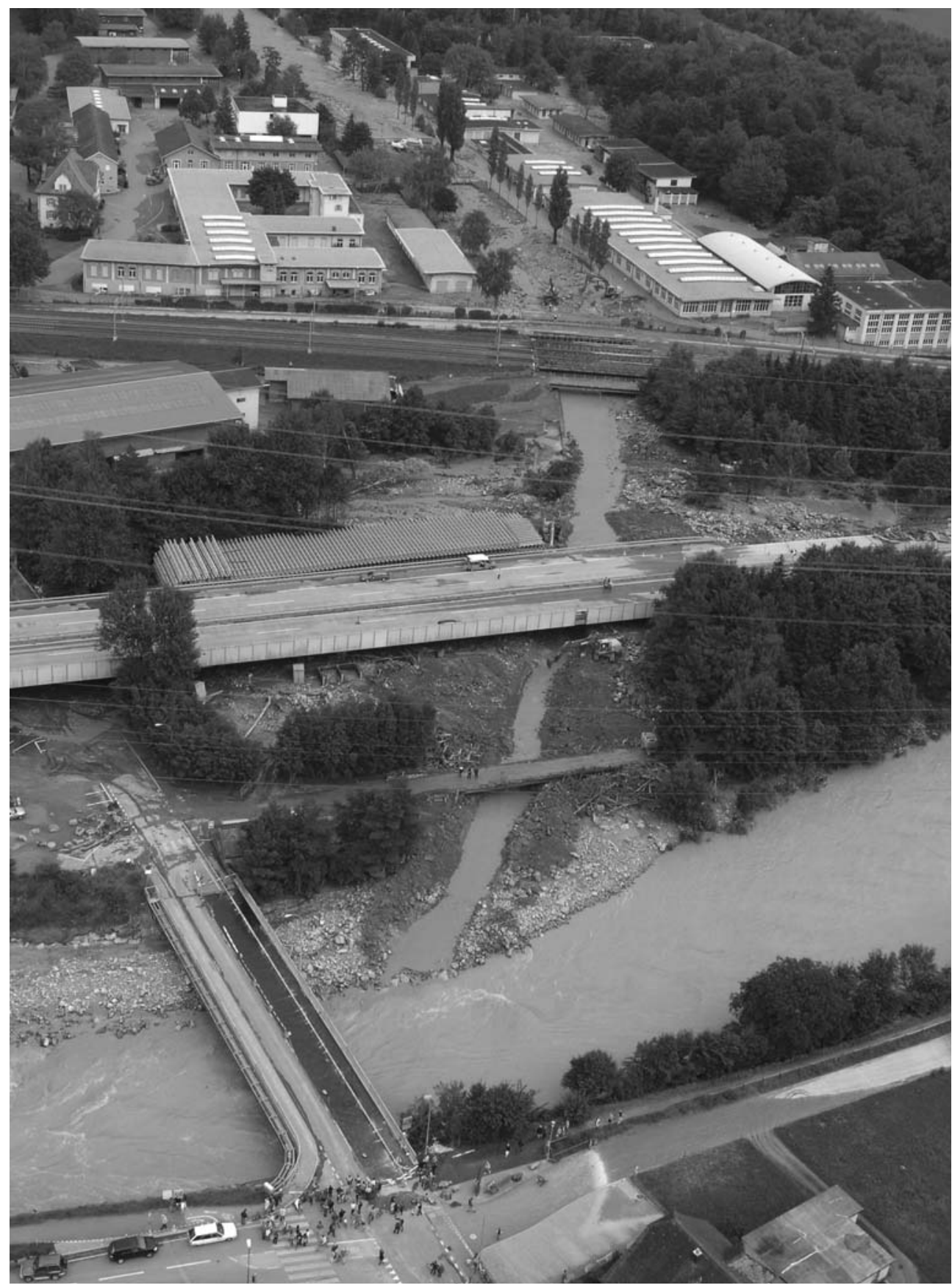

FIGURE 1. Confluence of the Reuss and Schächen rivers after the flood of August 22/23, 2005. The lined masonry channel of the tributary is completely filled with sediment, what caused inundation of the industrial zone in the background (courtesy Canton of Uri) 
The arrangement of the tributary and a drainage canal and the vulnerability shown by the event was inherited from the engineers who designed the first lined channel. It may therefore take decades before flood protection works are really tested by an extreme event and the consequences of poor planning or design which may not be apparent for a hundred years or more.

Figure 2 shows the results of the numerical simulation of sediment transport in the lined channel which forms the lowest reach of the Schächen river about $1.6 \mathrm{~km}$ long. The phenomena which were observed during the night of 22/23 August 2005 could well be reproduced. Shortly after midnight the water level in the main river Reuss rose above the side walls of the tributary. This was due to the high discharge in the Reuss river as well as substantial sediment deposition from the tributary. Consequently, water spilled over the side walls of the Schächen. This produced a sudden deposition of sediment in the last $100 \mathrm{~m}$ of the lined channel which blocked completely the flow section. Obviously, the overspilling water reduced the local transport capacity and favoured the blocking of the channel. Over the following hours the sediment arriving from upstream was caught in the blocking and thus a deposition front was moving upstream. Around $07 \mathrm{~h} 30$ in the morning this front had passed the railway bridge. In consequence, water and sediment spilt over both banks into the surrounding industrial area, causing extremely heavy damage. Until the end of the flood, the front moved up about $850 \mathrm{~m}$, marked by a hydraulic jump visible in the after flood documentation.

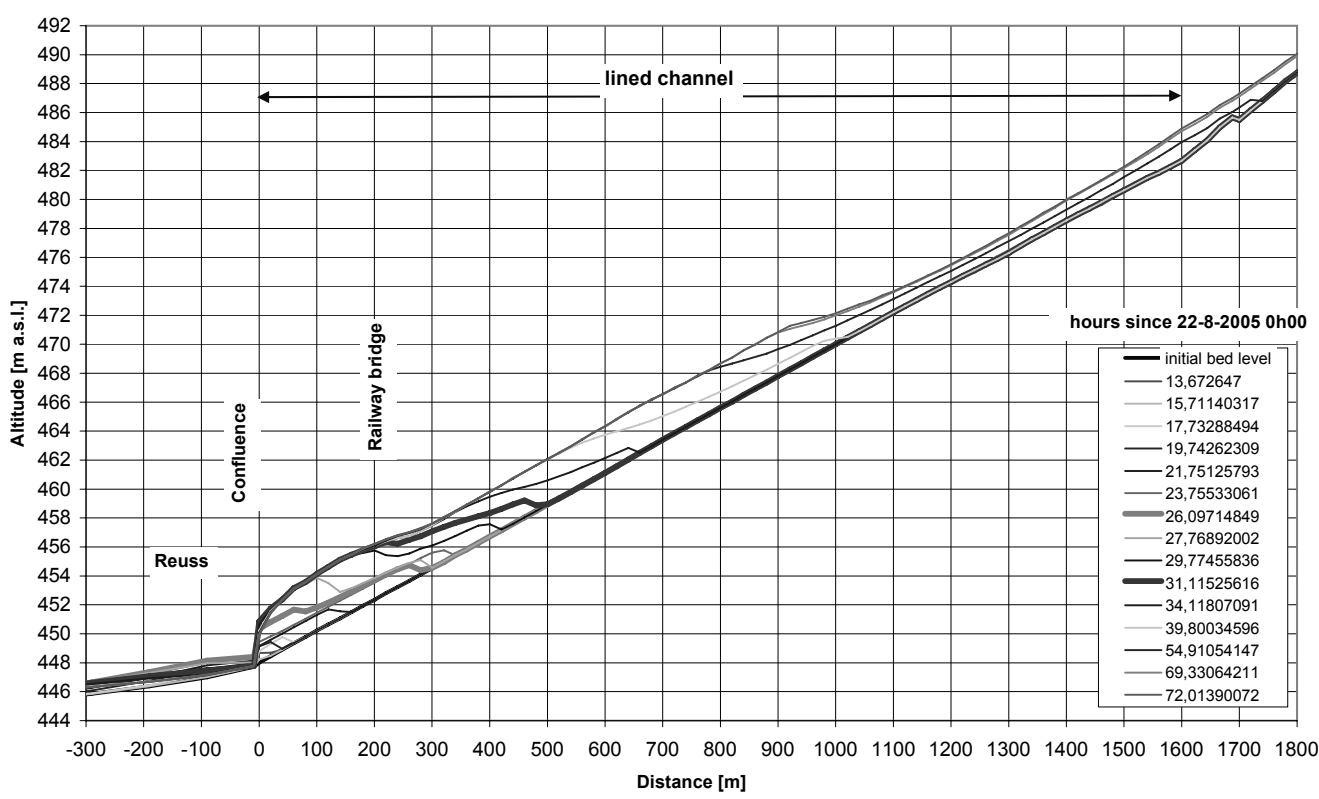

FIGURE 2. Results of the sediment transport simulation in the lowest reach of the Schächen river. Development of the blocking of the flow section near the confluence and upward movement of the deposition front 
The simulation was repeated for channel walls which were raised by $1.5 \mathrm{~m}$ in the lowest part and the railway bridge being replaced by so-called pressure bridge. With an upstream apron and adapted side walls the flow is forced under the bridge and blocking of the bridge section is prevented (Jaeggi 2007). With this arrangement no spilling over the side walls was observed and no blocking of the section occurred. Therefore, the high water level in the main river which induced overspilling of the side walls in the last reach of the tributary was the main cause of the inundation, since the sudden blocking of the section and the upstream movement of the deposition front finally produced the disaster.

\section{Performance of the upstream sediment detention dam}

After the 1977 event a sediment detention basin was built. Unfortunately, it could not be placed near the apex of the alluvial fan, where it would normally be positioned to mitigate the problem. For construction reasons it had to be moved about $1.5 \mathrm{~km}$ upstream. As shown below, in the intermediate reach the Schächen incised its bed and thus picked up about $50.000 \mathrm{~m}^{3}$ of very coarse sediment. This was the main sediment supply to the lined channel with the disastrous consequences.

The performance of the detention basin did however not meet the expectations. Figure 3 shows the detention basin with some deposition, towards the end of the flood. The volume retained behind the dam was far smaller than expected. The water level in the basin was mostly lower than the crest of the overflow section, what is reduced the detention volume. This was partly due to the size of the bottom outlet, which proved to be larger than in the original design. However, when the design was made it was taken for granted that the bottom outlet would be blocked by floating debris in case of major events. Although this outlet was $3.3 \times 4.5 \mathrm{~m}$ wide, the trees were sucked by the current through the bottom outlet without blocking it.

The dam was conceived as an open slit dam in 1980, when the project was set up. It was then very fashionable to favour open dams. The idea was that when the peak flow was reached, the excess material could be held back, and then during receding flow sediment again be released. It was thought that this could prevent erosion in the downstream reach and lower the maintenance costs. During this event, however, the release of sediment after the passage of the peak flow proved to be an aggravating factor. The lined channel in the lower part of the river was then already filled up by the sediment picked up in the intermediate reach. So the sediment released by the dam now also ended up in the channel already blocked, and also contributed to flood the industrial area beside the river channel.

Figure 4 shows the results of the simulation for the basin. During calibration, sediment supply from upstream and the hydraulic characteristics of the bottom outlet were varied until the performance after numerical model was satisfactory, compared to observations. Highly unsteady phenomena like water level oscillations in the basin, resulting from oscillating sediment deposition and erosion in the stilling basin and the outlet section, could be reproduced to some extent. Bezzola (2006) relates even the discharge oscillations to these phenomena. Since the 


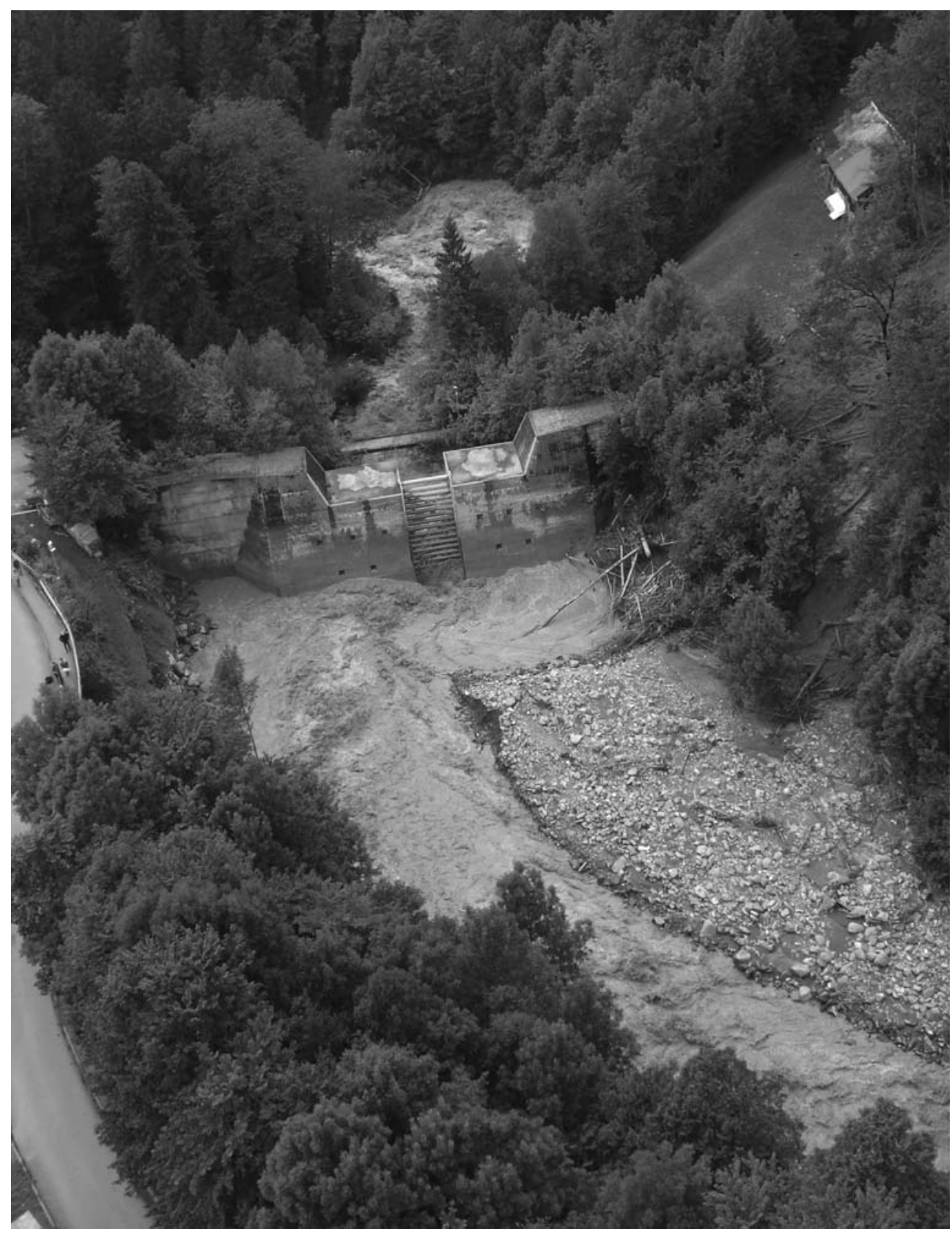

FIGURE 3. Sediment detention basin 'Stiglisbrücke', about $4 \mathrm{~km}$ upstream of the confluence, towards the end of the flood. A large part of the deposition visible on the right was flushed later during receding flow (courtesy Canton of Uri) 


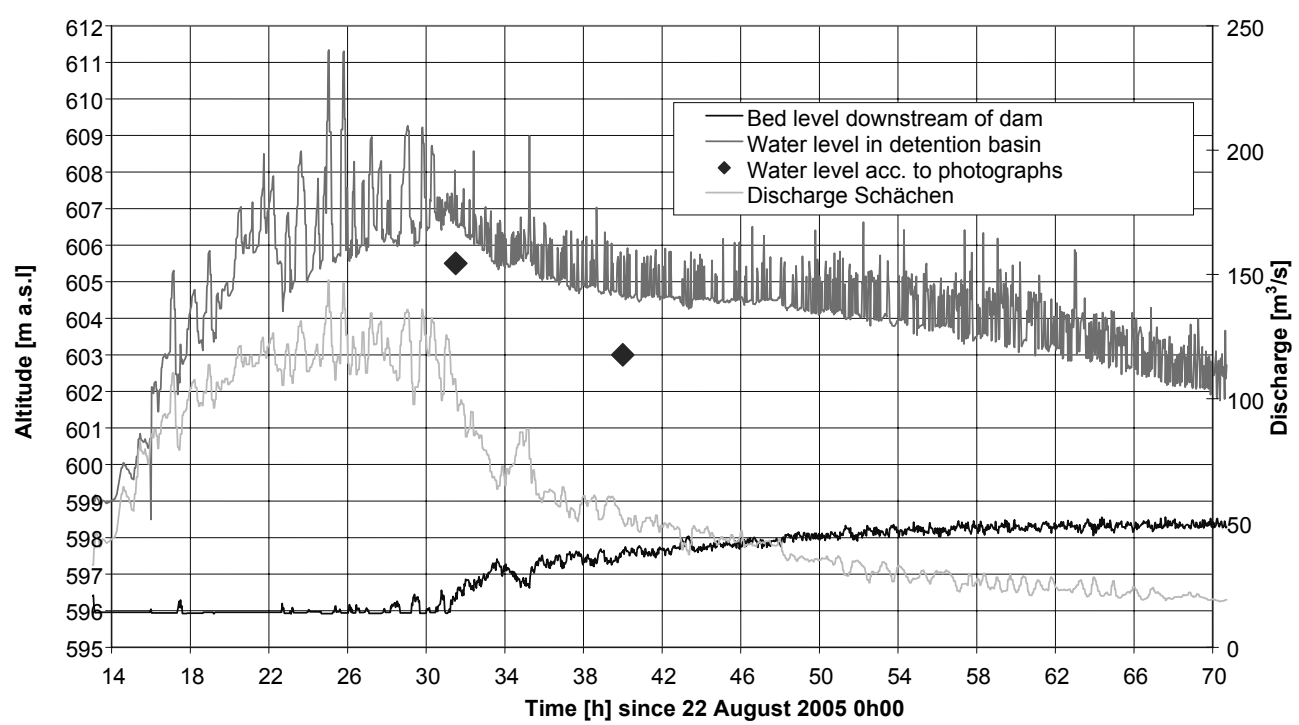

FIGURE 4. Water level in the detention basin and downstream deposition, resulting from numerical simulation

simulation model reproduces quasi-steady and not unsteady flow conditions, this hypothesis could not be verified.

During the receding limb of the flood, the simulated water level was higher than values taken from photographs. It is believed that this is resulting from the fact that a coarse grain size distribution was maintained for the sediment supply, whereas effectively the grain size distribution may have become finer and finer with decreasing flow.

\section{MOUNTAIN STREAM MORPHOLOGY OF THE INTERMEDIATE REACH}

In steep reaches of mountain streams, normally there is a strong stable armour layer. Big boulders, which were washed out from older deposits like debris flow fans, or fell from the rock flanks, are characteristic for the bed surface. They may form step like structures. Such step-pool structures formed by the flow may further increase stability (Whittaker and Jaeggi 1982). So, during ordinary floods, despite the steep slope, this stable structures prevent bed and bank erosion. Sediment transport is supply conditioned, and does not interfere with the bed material. The transport rates are far lower than according to the theoretical transport capacity of the steep reach.

During a very rare and extreme event, the boulders and the steps may be displaced by local scouring, which in turn releases finer sediment from the bed and the banks. Because of the bed instability, a general widening of the river bed as well as activation of meanders follows (see also Bezzola et al. 1990). Transport rates of the eroded material may now well correspond to the theoretical transport capacity, as given for instance by Smart and Jaeggi (1983). So there are clearly, two modes of sediment transport in such mountain rivers (Koulinski 1994). 
The intermediate reach of the Schächen river between the detention dam and the downstream lined channel exactly presents these characteristics (see Fig. 5). The bed is covered by very coarse boulders and one might expect full stability of the bed. But it was found that general incision occurred which amounted at least to $1 \mathrm{~m}$, sometimes up to $2.5 \mathrm{~m}$. Locally, subsequent bank collapses triggered slides. Totally, about $50.000 \mathrm{~m}^{3}$ were thus supplied to the downstream reach.

The threshold discharge for which the armour layer breaks and high sediment rates are released may be estimated by the procedure of Whittaker et al. (1988). It considers grain roughness which is function of the bed between the coarse boulders and form roughness produced by these boulders. The boulders are characterised by an equivalent sphere diameter $D . n$ is their density (number of boulders per square meter, i.e. $0.1 ; 0.2$ etc.). Now, the roughness height of a fictive roughness element $k_{B}$ is determined, with $h_{m}$ being the mean flow depth:

$$
k_{B}=n \cdot D^{3} \cdot\left(17.8-0.47 \cdot \frac{h_{m}}{D}\right)
$$

The energy losses being split, it follows:

$$
\begin{aligned}
& c_{B}=2.5 \cdot \ln \frac{12.3 \cdot h_{m}}{k_{B}} \text { (form roughness) } \\
& c_{s}=2.5 \cdot \ln \frac{12.3 \cdot h_{m}}{2 \cdot d_{90}} \text { (grain roughness) }
\end{aligned}
$$

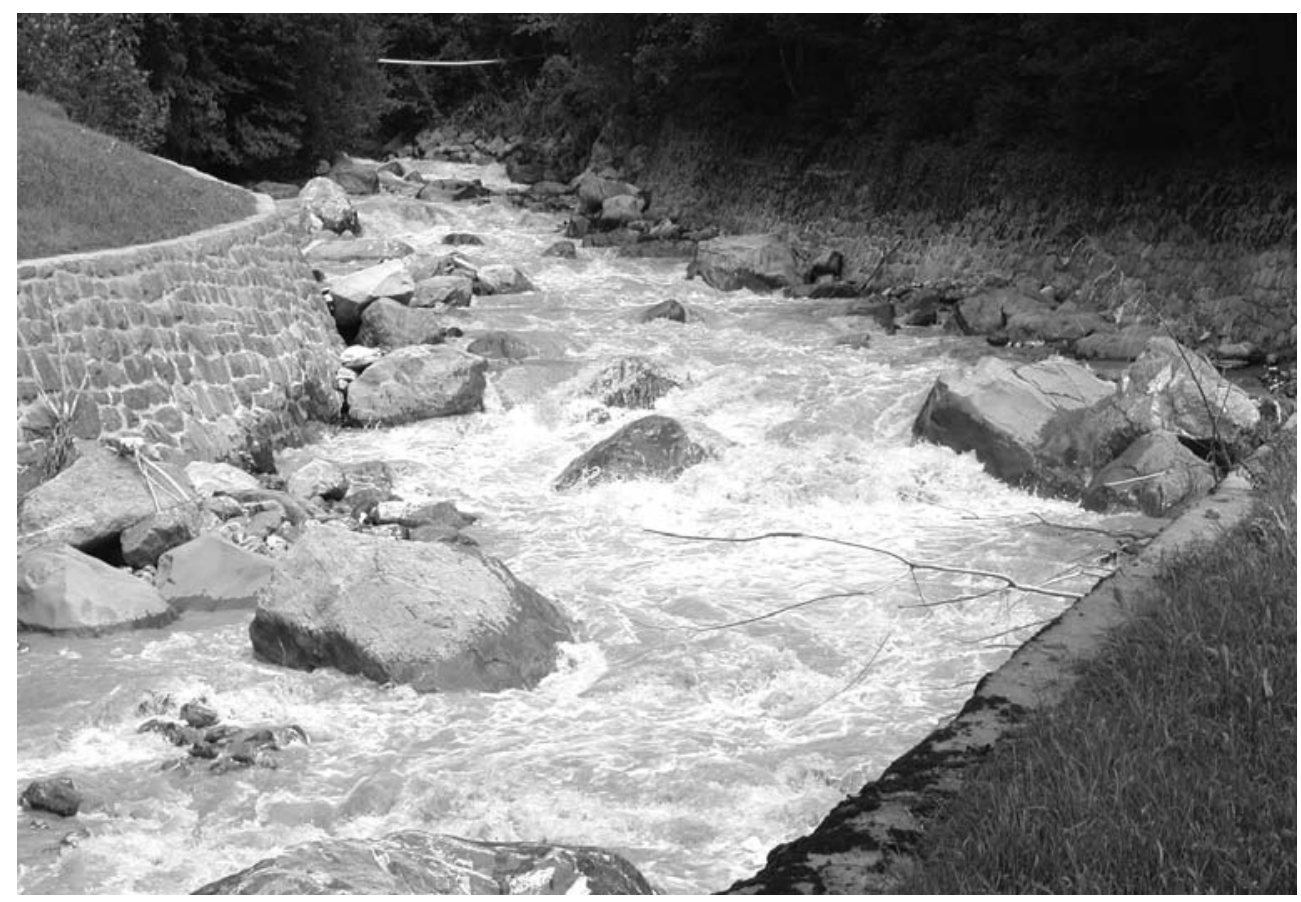

FIGURE 5. Intermediate reach downstream of the detention basin. Despite apparent stability, incision exceeding 1 to $1.5 \mathrm{~m}$ occurred 
and

$$
\frac{1}{c^{2}}=\frac{1}{c_{s}^{2}}+\frac{1}{c_{b}^{2}}
$$

by definition,

$$
c=\frac{v_{m}}{v_{*}}=\frac{v_{m}}{\sqrt{g \cdot h_{m} \cdot J}}
$$

for known values of $h_{m}$ and $J$ the value of $v_{m}$ results. Finally,

$$
c_{s}=\frac{v_{m}}{v_{*}^{\prime}}=\frac{v_{m}}{\sqrt{g \cdot h_{m} \cdot J^{\prime}}}
$$

and

$$
J^{\prime}=\frac{v_{m}^{2}}{c_{s}^{2} \cdot g \cdot h_{m}}
$$

the bed remains stable, if

$$
\frac{h_{m} \cdot J^{\prime}}{(s-1) \cdot d_{m}}<\theta_{c r} \cong 0.05
$$

for a widely graded bed material with a self armouring tendency, there is

$$
\frac{h_{m} \cdot J^{\prime}}{(s-1) \cdot d_{m}}<\theta_{D}=0.05\left(\frac{d_{90}}{d_{m}}\right)^{2 / 3}
$$

using a formula of Günter (1971). $d_{m}$ is the mean grain size of the substrate, $d_{90}$ represents the grain of the substrate which is coarser than $90 \%$ of the material by weight. It is taken as an approximation for the mean grain size of the armour layer.

With this method it could be assessed that in the intermediate reach a discharge of about 80 to $100 \mathrm{~m}^{3} / \mathrm{s}$ would correspond to the stability limit of the bed. From photographs of value of $D$ of about $1.4 \mathrm{~m}$ and $n$ of about 0.1 where estimated. In the flatter reach of about 5\% slope a bed width of $12 \mathrm{~m}$ was introduced in the calculation, in a steeper reach of about $9 \%$ slope the corresponding bed width was $20 \mathrm{~m}$.

\section{Sediment balance}

Numerical simulation of sediment transport during the event allowed to give an overall picture of sediment moved as coarse bedload. The results are presented in Figures 6 and 7. Figure 6 shows the cumulated sediment yields along the simulated river reach, Figure 7 the volumes introduced. The red curve represents the moment when water and sediment spilt out of the downstream reach. Simulation is more precise before that moment and more qualitative after that. It can be seen that most of the sediment which contributed to the blocking of the confluence section and the front moving upstream came from the intermediate reach. The detention dam had some positive effect during the first phase of the event, it is only later that the self flushing effect occurred.

According to Figure 7, a volume of about $70.000 \mathrm{~m}^{3}$ of coarse sediment was introduced into the system until the moment when large scale inundation started. Over the whole simulation period the volume was about $110.000 \mathrm{~m}^{3}$. These values corresponded reasonably well with the depositions recorded in the Reuss river, in the lined channel of the Schächen and in the industrial areas in the immediate vicinity of the channel. The total volumes cleared from the area where about five times higher, but this material proved to be mainly sand and silt. 


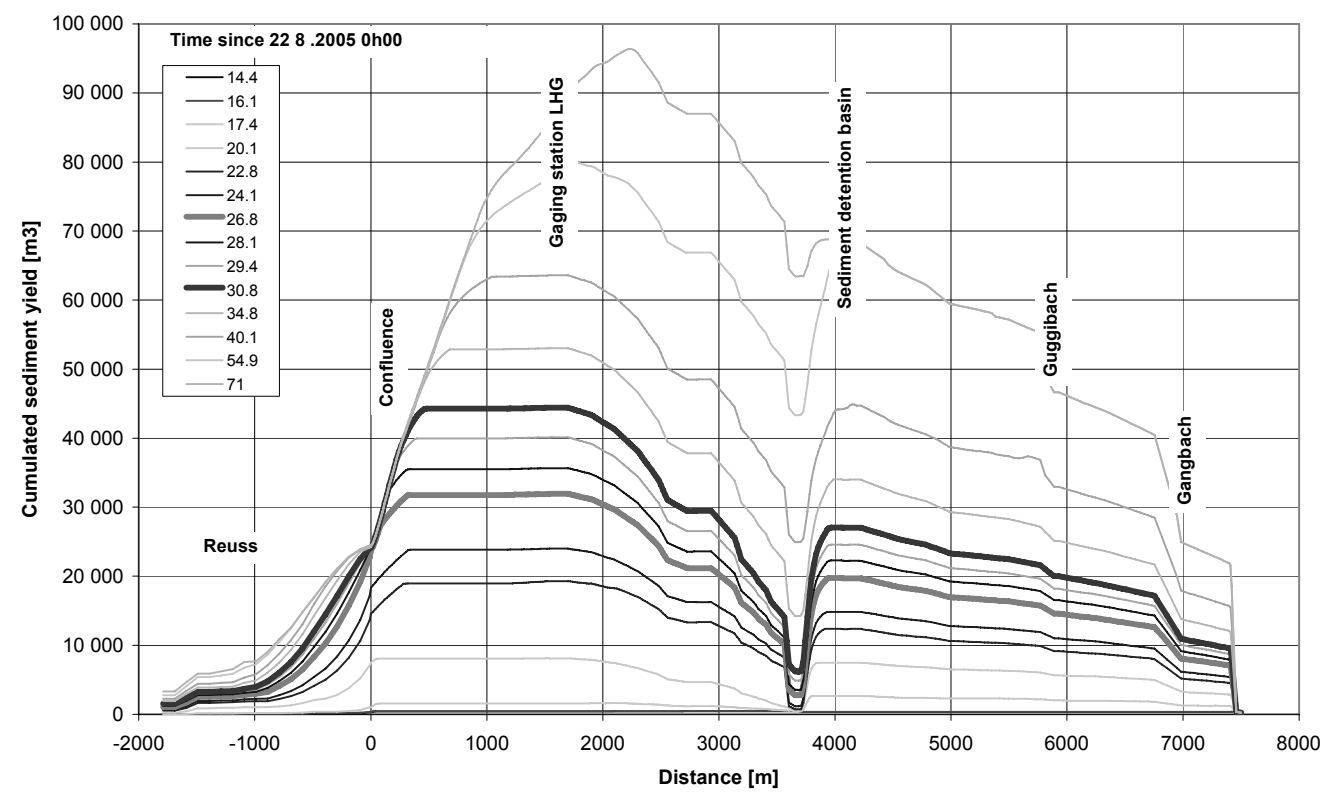

FIGURE 6. Variation of sediment (coarse bedload) transport during the flood of August 2005 in the Schächen river, as calculated by the numerical model

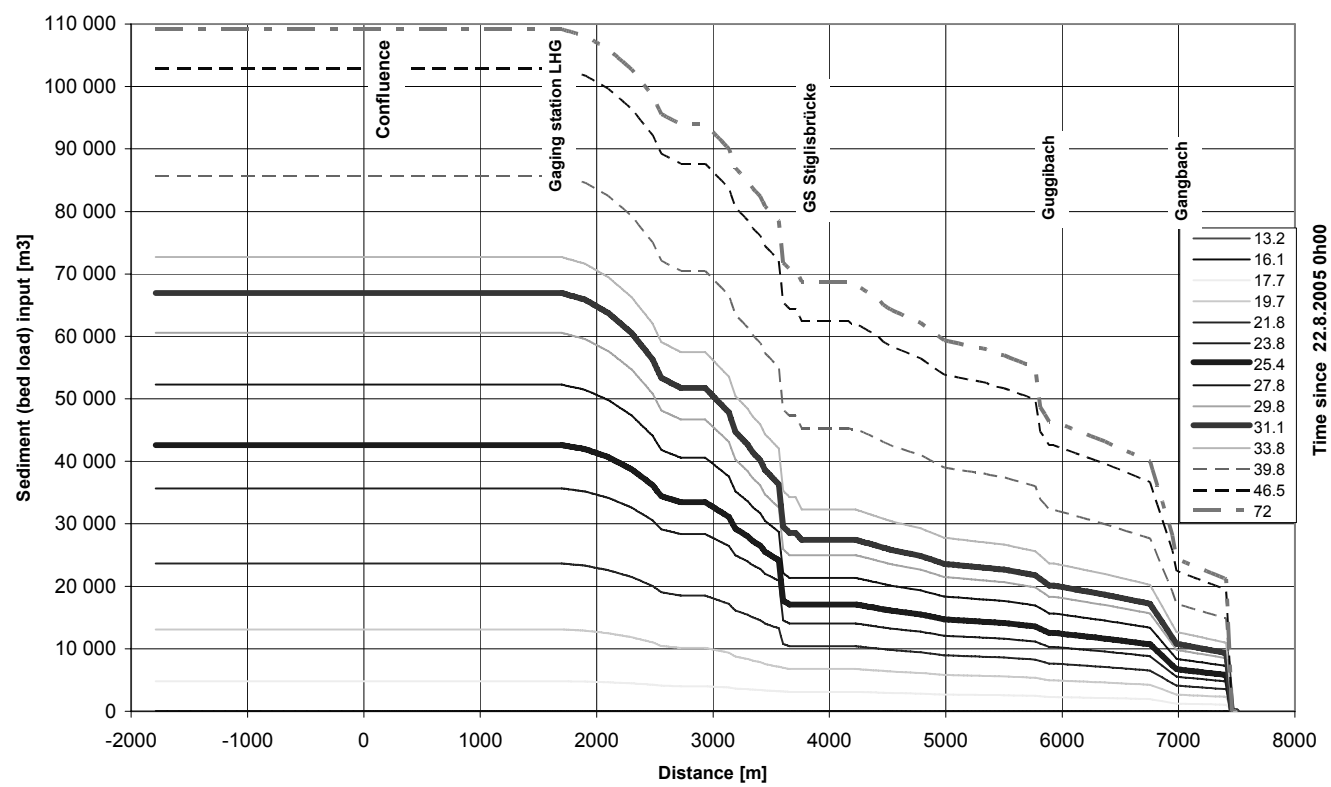

FIGURE 7. Input of coarse bedload material into the Schächen river during the flood event, as calibrated by the numerical model 


\section{THE LÜTSCHINE RIVER} IN LÜTSCHENTAL

The Lütschine river (Schwarze Lütschine in the upper course) caused many problems between the well-known resorts of Grindelwald and Interlaken (Canton of Berne, Jungfrau region). In the upper part, there is succession of steeper and flatter reaches. Strong erosion occurred in the steeper zones, causing bank collapse which in turn destroyed roads, railway lines and bridges. In the flatter reaches strong deposition caused flooding and local lateral erosion with subsequent damage. Figure 8 shows flooding in the village of Lütschental. The activation of a meander bend is seen in the background, where the railway and the road leading to Grindelwald were cut. In the foreground a road bridge can be seen, which was destroyed because of general deposition which induced the flow to attack the right abutment. Since this was not deeply founded the bridge collapsed.

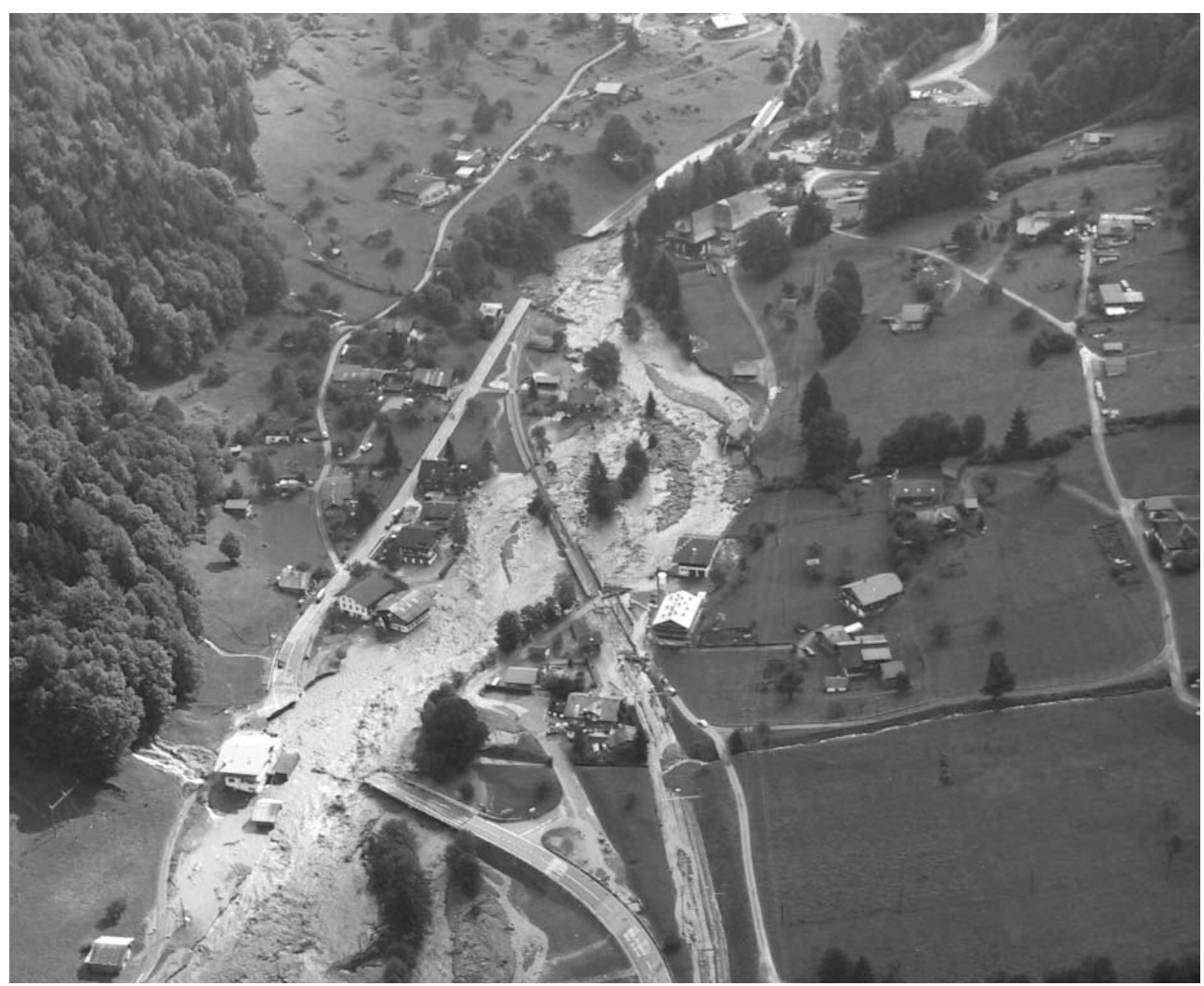

FIGURE 8. The village of Lütschental on the Schwarze Lütschine (near Grindelwald, Canton of Berne). Lateral erosion occurred because of heavy deposition, leading to bridge collapses. Destabilisation of boulder structures in the steeper reach of the background was at the origin of deposition and induced also a strong meander tendency 


\section{Erosion in the steep reach}

Very similarly to what happened in the Schächen river, the steep reach upstream of the village is normally stabilised by big boulder structures. In these extreme and long-lasting flood event, about $100.000 \mathrm{~m}^{3}$ of bedload material has been brought into motion. Again it was estimated that only a discharge with an extremely high recurrence interval is able to destabilise the bed in his reach. Erosion was accompanied by a strong meander tendency, leading the local bank collapses and is threatening the road bridges and farmhouses.

\section{Deposition process}

As Figure 9 shows, the slope of the river substantially decreases in the village and downstream of it. However, it is not known that during normal floods deposition occurs there. If therefore are really needed the heavy input from the steep reach upstream reach obviously occurs only rarely. A wooden bridge was destroyed in the village of Lütschental which was believed to be about 120 years old. It seems therefore that the discharge during this period was never as high as during the event of 2005 , or at least was reached only for a very short duration.

Again a numerical simulation of sediment transport processes was performed. The results are shown in Figures 9 and 10. Reproducing the depositional profile, volume of the input and grain size distribution could be calibrated. The sediment balance illustrated by Figure 10 shows that in such an event most of the sediment mobilised in the upstream reach will be deposited and has no chance to be moved to the downstream reaches. The main goal of the numerical simulation was to use the calibrated model to test the protection concept.

\section{Protection concept}

For the steep upper reach it was decided to generally accept the new shape of the channel. Local bank protection is set up using heavy concrete elements (see Fig. 11). Such methods have been described by Bezzola (1992 and 2005) or Jaeggi and Philipona (2004). In the potential deposition zones in the village and downstream of it, the river bed will be dredged to the original level. This will be considered to be a depositional area for future events. Since it is believed that only very rare events will actually bring into motion heavy loads of sediment, the threatened areas can still be used by agriculture. Construction of buildings will however be prohibited there. Reconstruction of the road bridge has to consider the deposition process and the flood levels on a deposition while during extreme flood event. Slope reduction will be concentrated in a short reach, where eventual sediment depositions can be monitored and excavated is necessary.

\section{CONCLUSIONS}

The flood events of August 20-23, 2005 in Switzerland showed once again the relevance of the specific morphology of mountain streams with a slope range of 5 to $15 \%$. Although they remain stable for lower and medium floods because of the presence of large boulders, their destabilisation during rare events may trigger important sediment loads. The longer the duration of a stable period of the lower floods has been, the more the morphological changes are surprising to 


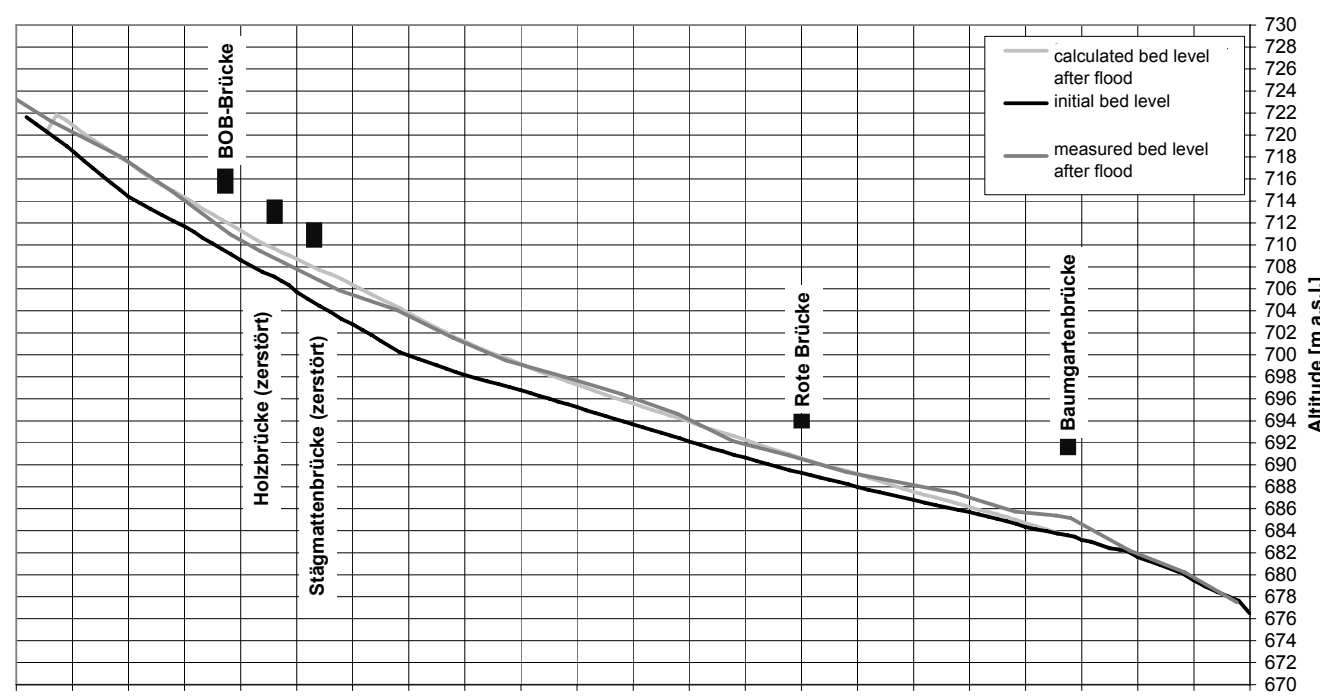

48004700460045004400430042004100400039003800370036003500340033003200310030002900280027002600

Distance $[\mathrm{m}]$

FIGURE 9. Calibration of the numerical sediment transport model in the reach of Lütschental

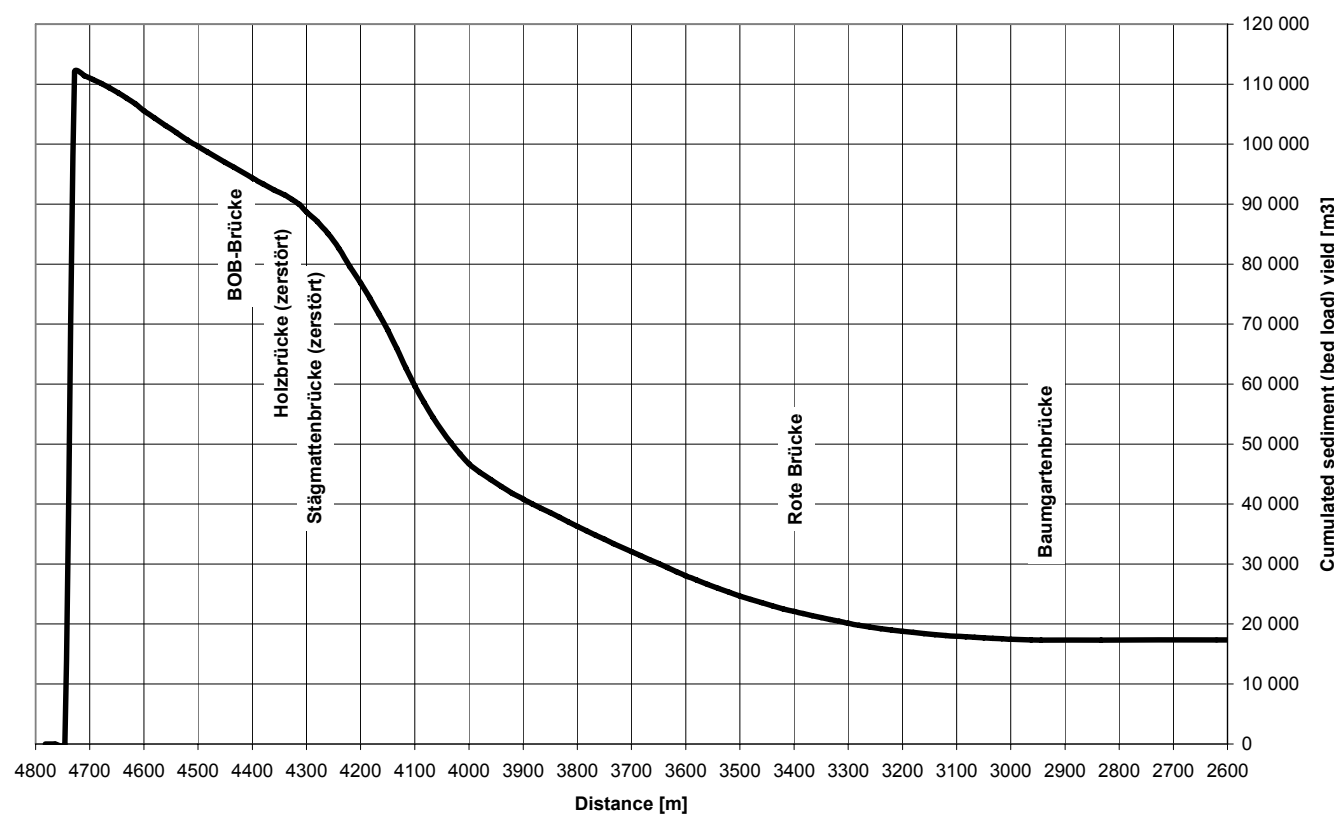

FIGURE 10. Variation of sediment transport, along the Lütschental reach, resulting from numerical simulation; illustrating the strong deposition tendency during extreme flood events 


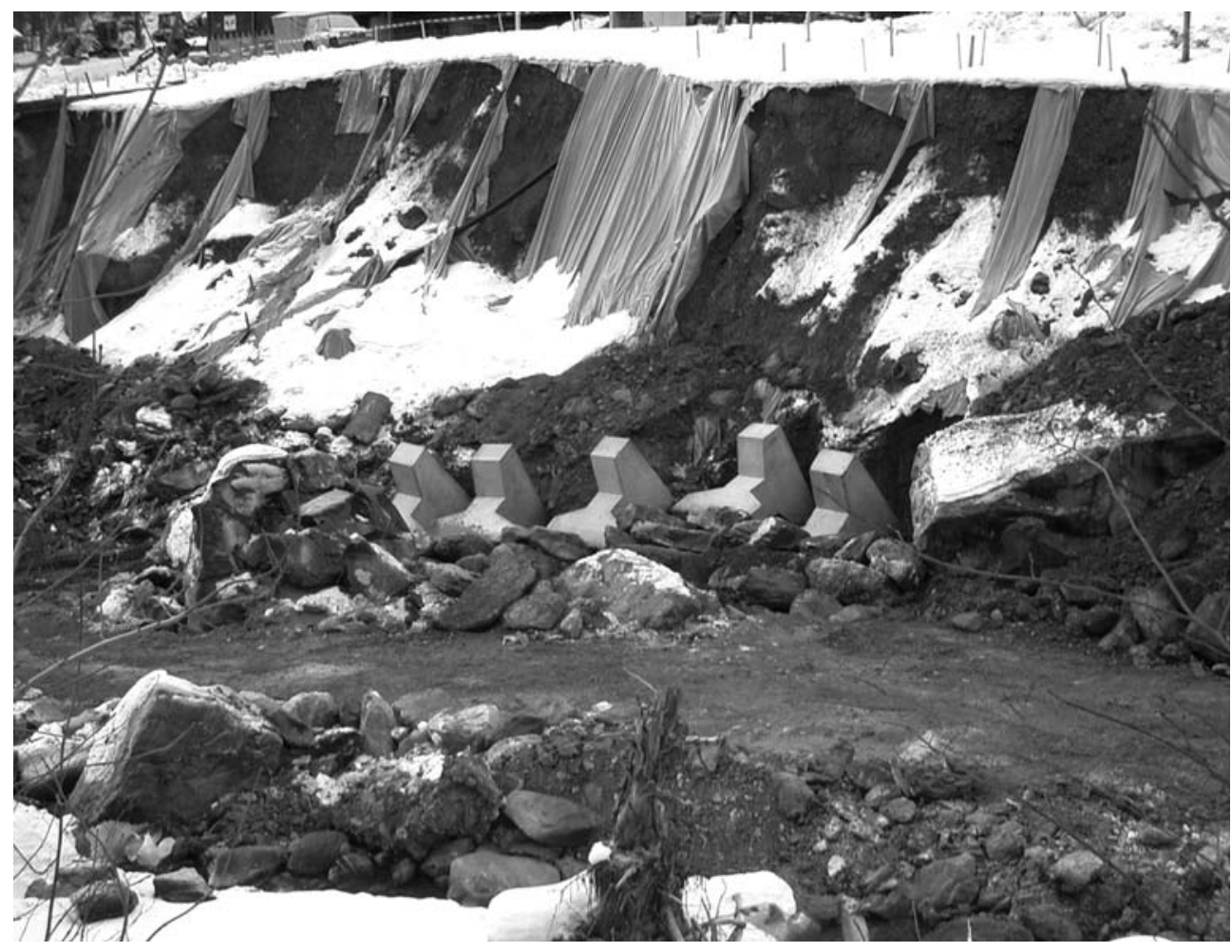

FIGURE 11. Use of heavy concrete polypode elements to increase local erosion resistance, in the steeper part of the Schwarze Lütschine river

the local people. In the case of the floods of the Lütschine it may well be that such an extreme flood, able to break the armour layer in the steep reach, had not occurred since about 1850 . Such rivers may be compared to dormant volcanoes (Jaeggi 1995).

The performance in terms of sediment transport capacity of lined masonry channels has been overestimated in the past. Boundary conditions, like the local sediment transport capacity of the main river, may become the limiting factor, as shown in case of the Schächen River. Sediment carried through the lined channel could not be moved away at the confluence. Lateral overspilling, which was a consequence of the rising water level in the main river, may soon lead to a complete blocking of a channel, as demonstrated by numerical simulation. Sufficiently high banks could prevent this to happen.

Open slit dams which were very fashionable some years ago do not perform satisfactorily. They retain sediment completely, when the water level behind the dam rises in function of discharge. During peak flow, erosion in the downstream reach is favoured. With the drawdown during receding flow high transport rates occur through the dam. In case of the Schächen river, this amount of sediment arrived in the downstream reach at a moment when 
the channel was already overloaded and thus the problems were aggravated there. The basin on the Schächen has therefore to be equipped with a regulating gate. So, during frequent floods harmless sediment loads can be moved through a large bottom outlet section. In emergency situation when aggradation in the downstream area has to be feared, the bottom outlet will be closed to obtain maximum sediment retention capacity.

If, as in the Lütschine river, heavy sediment loads are to be expected only in function of the rare destabilisation of a mountain stream reach, planning of detention areas may allow a limited land use. It is important then to obtain deposition only by slope reduction and channel widening.

The described events showed furthermore that the failure of flood protection systems leads to increasingly greater damage as floodplain development expands, for housing, transportation, industrial development or commerce. If extreme events are absent for decades, land use may have dramatically changed between events. Even long discharge measurement records are insufficient to give a precise answer concerning recurrence of rare floods and to define a design flood. Protection systems have therefore to be designed in such a way that overloading does not induce a complete failure of the system.

\section{REFERENCES}

BEZZOLA G.R., KUSTER P., PELLANDINI S. 1990: The Reuss River Flood of 1987 Hydraulic Model Tests and Reconstruction Concepts. International Conference on River Flood Hydraulics, Wallingford, UK, 17-20 Sept., 1990, paper J2, 317-326.
BEZZOLA G.R. 1992: Eine neuartige Verbauungsmethode in Gebirgsflüssen, wasser energie luft, 84.

BEZZOLA G.R. 2005: Von der Küste in den Wildbach, Erosionschutz mit Betonelementen, Wasser Energie Luft, 97. Jahrgang, Heft 9/10, 289-296.

BEZZOLA G.R. 2006: Federal Office fort he Environment, Geschiebesammler Stiglisbrücke, Interpretation des Verhaltens während des Hochwassers vom 22/23 August 2005. Internal notice, 12.1.2006.

BEZZOLA G.R., HEGG Chr. (ed.) 2007: Ereignisanalyse Hochwasser 2005, Teil 1 - Prozesse, Schäden und erste Einordnung, Federal Office for the Environment, Berne

Jahrgang. Heft 11/12, Baden (CH) 331-333.

GÜNTER A. 1971: Die kritische mittlere Sohlenschubspannung beiGeschiebemischungen unter Berücksichtigung der Deckschichtbildung und der turbulenzbedingten Sohlenschubspannungsschwankungen, Mitteilungen der Versuchsanstalt für Wasserbau, Hydrologie und Glaziologie $\mathrm{Nr} 3$.

JAEGGI M.N.R. 1995: Sediment Transport in Mountain Rivers - A Review, Proc. of the International Sabo Symposium, Tokyo, Japan, August.

JAEGGI M., PHILIPONA B. 2004: Einbau von künstlichen mehrfüssigen Blöcken aus armiertem Beton im Riggisalpbach (Kanton Freiburg), Fan-Agenda Nr. 2, Fachleute Naturgefahren Schweiz, 11-15.

JAEGGI M. 2007: Sediment transport capacity of pressure flow at bridges, Proceeding of the 32nd Congress of the International Association for Hydraulic Research and Engineering, Topic A.2.b linear transport, July 1-6, Venice, Italy.

JAEGGI M. 2008: The floods of August 22-23 2005, in Switzerland: some facts and challenges, in Gravel Bed Rivers VI, from process understanding to river restoration, edited by Habersack H., Piégay H., Rinaldi M. Developments in earth surface processes 11, Elsevier, 587-604.

KOULINSKI V. 1994: Etude de la formation d'un lit torrentiel, Etudes équipements pour l'eau et l'environnement, Centre national du machinisme agricole, du génie rural, des eaux et des forêts, Grenoble.

SMART G.M., JAEGGI M. 1983: Sedimenttransport in steilen Gerinnen. Sediment transport 
on steep slopes. Mitteilung der Versuchsanstalt für Wasserbau, Hydrologie und Glaziologie der ETH Zürich, Nr 64.

WHITTAKER J.G., JAEGGI M. 1982: Origin of Step-Pool Systems in Mountain Streams. Proceedings of the ASCE, J. of the Hydraul. Division, Vol. 108, HY 6, 758-773.

WHITTAKER J.G., HICKMAN W.E., CROAD R.N. 1988: Riverbed Stabilisation With Placed Blocks, Central Laboratories Report 3-88/3, Hydraulics Section, Central Laboratories Works Corporation, Lower Hutt, NZ.

Streszczenie: $O$ pewnych aspektach transportu rumowiska $w$ czasie powodzi z 2005 roku w Szwajcarii. Bardzo groźna powódź nawiedziła dużą część Szwajcarii w sierpniu 2005 roku.
Efektem była bardzo silna erozja na kilku górskich, dotychczas stabilnych, odcinkach rzek, co wywołało transport olbrzymich ilości rumowiska rzecznego. W miejscach odkładania się rumowiska następowały ograniczenia przepustowości i przetasowania koryta oraz wywołane nimi podpiętrzenia. Symulacja komputerowa okazała się być użytecznym narzędziem $\mathrm{w}$ analizie procesu i w planowaniu usuwania skutków powodzi.

MS. received April 2008

Author's address:

Bergholzweg 22

CH-8123 Ebmatingen

Switzerland 